Bangladesh J. Bot. 47(3): 389-395, 2018 (September)

\title{
MYCOFLORA ASSOCIATED WITH POST-HARVEST DISEASE OF PAPAYA (CARICA PAPAYA L.) AND THEIR PATHOGENIC POTENTIALITY
}

\author{
Rezuana Binte Helal, Sarowar Hosen and Shamim Shamsi* \\ Department of Botany, University of Dhaka, Dhaka-1000, Bangladesh
}

Keywords: Mycoflora, Diseased fruits, Carica papaya, Pathogenic potentiality.

\begin{abstract}
Nineteen species of fungi namely, Alternaria alternata (Fr.) Keissler, Aspergillus flavus Link, A. fumigatus Fresineus, A. niger Van. Tieghhm, Colletotrichum dematium (Pers.) ex. Fr., C. gloeosporioides (Penz.) Sacc., Corynespora citricola M.B. Ellis, Curvularia lunata Wakker, Fusarium flocciferum Corda, $F$. nivale (Fr.) Ces., Fusarium Link, Lasiodiplodia theobromae (Pat.) Griff \& Moubl, Monilia Pers., Mucor Fresen, Penicillium Link, Pestalotiopsis guepinii (Desm.) Stay., Rhizoctonia solani J.G. Kuhn, Rhizopus stolonifer Bull. and Syncephalastrum Schroet were found to be associated with the diseased fruits of Carica papaya L. Among the isolated fungi $C$. gloeosporioides, F. nivale and Fusarium sp. were found to be pathogenic for both red and yellow cultivar Shahi papaya. Association of C. lunata, F. nivale, P. guepinii and Syncephalastrum sp. with papaya is a new record. The present report is the first record of Corynespora citricola and Fusarium flocciferum from Bangladesh.
\end{abstract}

\section{Introduction}

Papaya (Carica papaya L.) is one of the most important fruits cultivated throughout the tropical and subtropical regions of the world (Ahmed et al. 2008). It is consumed at unripe and ripe stages (Mendoza 2007). The edible portion of the ripe papaya fruit contains $\mathrm{Na}, \mathrm{K}, \mathrm{Ca}, \mathrm{Mg}, \mathrm{P}$, $\mathrm{Fe}, \mathrm{Cu}, \mathrm{Zn}$ and $\mathrm{Mn}$. It is a source of carotenoids, vitamin $\mathrm{C}$, thiamine, riboflavin, niacin, vitamin B-6 and vitamin K (Bari et al. 2006). Bangladesh is one of the major papaya producing countries along with Brazil, China, India, Indonesia, Mexico, Thailand etc. Bangladesh produces 133370 million tones of ripe papaya fruits annually from 3126 acres of land (Anon. 2015). In Bangladesh, Shahi papaya released by BARI is only a single recommended variety of the crop (Ara et al. 2013). Post-harvest losses due to fungal infections are significantly high in papaya fruits. Various fungi cause rots in fruits of papaya (Sawant and Gawai 2011). The post-harvest pathogens like Colletotrichum gloeosporioides (Penz.) Sacc., Botryodiplodia theobromae Pat., Alternaria, Phomopsis, Fusarium, Aspergillus, Stemphylium and Pestalotiopsis attack the fruits and cause considerable damage to fruit production and quality (Chowdhury et al. 2014). Six post-harvest diseases of papaya viz., Anthracnose, Aspergillus rot, Fusarium rot, Penicillium rot, Rhizopus rot and stem end rot were recorded in Bangladesh (Hamim et al. 2014). The post-harvest fruit rots bring about a big loss in fruit business which provokes price hike (Uddin 1995). Investigation on post-harvest diseases and associated mycoflora of Shahi papaya is limited in Bangladesh (Chowdhury et al. 2014, Hamim et al. 2014). For the above reasons present research was undertaken to find out the association of fungi with Shahi papaya fruits and their pathogenic potentiality.

\section{Materials and Methods}

Fruits of red and yellow Shahi papaya variety were collected from five different markets of Dhaka namely, Segunbagicha bazaar, Shantinagar bazaar, Karwan bazaar, Sham bazaar (Shoarighat) and Polashi bazaar during April, 2016 to November, 2016.

*Author for correspondence: <prof.shamsi@gmail.com>. 
Each market was visited four times about one-month interval to collect samples. During every visit, one for each of the red and yellow Shahi papaya showing anthracnose and rot was collected randomly. Fungi associated with diseased papaya were isolated immediately after collection following Tissue planting method (CAB 1968).

The microscopic structural characters of the isolated fungi were recorded with a digital camera. Morphological structures of the fungi were drawn in detail with the help of camera lucida. Identities of the isolates were determined following standard literatures (Thom and Raper 1945, Booth 1971, Ellis 1971, Barnett and Hunter 1972, Sutton 1980).

For pathogenicity test healthy papaya were collected from the selected five markets. Conidia of different fungi cultured on PDA plates were taken and conidial suspensions $\left(10^{5} / \mathrm{ml}\right)$ were made separately from hemocytometer count.

Papayas were washed thoroughly in running tap water and dipped in one liter of $10 \%$ Chlorox solution for three min for surface sterilization. Then papayas were washed three times in sterilized distilled water to remove 10\% Chlorox solution from the surface. Excess water from the surface of the papaya was removed by pressing them between two sheets of previously sterilized filter paper. Suitable sized plastic boxes were wiped with $70 \%$ alcohol and sterilized wet cotton was placed in a corner of box to maintain moisture content. Before spraying, the fruits were scratched with sterilized needle. Then fruits were inoculated by spraying the conidial suspension $\left(10^{5} \mathrm{conidia} / \mathrm{ml}\right)$ of 19 isolated fungi from diseased Shahi papaya with an atomizer (Tarl rops, Germany) and placed into separate plastic boxes. In control set, sterilized distilled water was used instead of conidial suspension on the sterilized papaya surface. The inoculated fruits with plastic boxes were incubated at $25-28^{\circ} \mathrm{C}$ for $7-10$ days. Observation was made after $7-10$ days of inoculation and symptoms developed on the fruits surface were recorded.

Re-isolation of the pathogen was made from the artificially infected papaya following the usual procedure. The morphological characters of the re-isolated fungi were compared with the original isolation by which they were inoculated.

\section{Results and Discussion}

Anthracnose and fruit rot symptoms were recorded on diseased Shahi papaya fruits. The fungi associated with diseased papaya and their per cent frequencies of occurrence are presented in Tables 1 - 2. A total of 19 fungi viz., Alternaria alternata, Aspergillus flavus, A. fumigatus, A. niger, Colletotrichum dematium, C. gloeosporioides, Corynespora citricola, Curvularia lunata, Fusarium flocciferum, F. nivale, Fusarium sp., Lasiodiplodia theobromae, Monilia sp., Mucor sp., Penicillium sp., Pestalotiopsis guepinii, Rhizoctonia solani, Rhizopus stolonifer and Syncephalastrum sp. were isolated from the diseased papaya. C. dematium and $F$. flocciferum were isolated from yellow Shahi papaya whereas C. lunata, Monilia sp. and Rhizoctonia solani were isolated from red Shahi papaya.

Sixteen fungi were isolated from diseased yellow Shahi papaya collected from five different markets of Dhaka city (Table 1). The per cent frequency of $C$. gloeosporioides was highest (40.91) whereas A. niger was lowest (4.47) in Segunbagicha bazaar. In Shantinagar bazaar the per cent frequency of C. gloeosporioides was highest (24.46) whereas Rhizopus stolonifer was lowest (2.60). Fusarium sp. showed highest (17.44) per cent frequency whereas Syncephalastrum sp. showed the lowest (3.35) in Karwan bazaar's samples. Fusarium sp. showed highest (24.21) per cent frequency and $R$. stolonifer showed lowest $(0.55)$ in the samples collected from Sham bazaar. In the sample collected from Polashi bazaar, the per cent frequency of $C$. gloeosporioides was highest (30.92) and Penicillium sp. was lowest (3.34). 
Table 1. Per cent frequency of fungi associated with diseased yellow Shahi papaya collected from different markets of Dhaka city.

\begin{tabular}{lccccc}
\hline $\begin{array}{l}\text { Name of } \\
\text { fungi }\end{array}$ & $\begin{array}{c}\text { Segunbagicha } \\
\text { bazaar }\end{array}$ & $\begin{array}{c}\text { Shantinagar } \\
\text { bazaar }\end{array}$ & $\begin{array}{c}\text { Karwan } \\
\text { bazaar }\end{array}$ & $\begin{array}{c}\text { Sham } \\
\text { bazaar }\end{array}$ & $\begin{array}{c}\text { Polashi } \\
\text { bazaar }\end{array}$ \\
\hline Alternaria alternata & - & 4.69 & 5.28 & 6.67 & 5.00 \\
Aspergillus flavus & 5.71 & - & - & 1.48 & 3.67 \\
A. fumigatus & 21.73 & 7.00 & 11.50 & 7.87 & 5.95 \\
A. niger & 4.47 & 4.51 & 6.86 & 9.39 & 10.89 \\
Colletotrichum dematium & - & - & 16.40 & - & - \\
C. gloeosporioides & 40.91 & 24.46 & - & 16.57 & 30.92 \\
Corynespora citricola & - & 9.20 & 10.45 & - & 13.41 \\
Fusarium flocciferum & - & 10.45 & - & 20.30 & - \\
F. nivale & 22.23 & 12.36 & 15.12 & - & 12.98 \\
Fusarium sp. & - & & 17.44 & 24.21 & 10.13 \\
Lasiodiplodia theobromae & - & 20.74 & - & 11.10 & - \\
Mucor sp. & - & - & - & - & 3.67 \\
Penicillium sp. & 9.86 & - & - & - & 3.34 \\
Pestalotiopsis guepinii & - & - & 10.45 & 1.91 & - \\
Rhizopus stolonifera & - & 2.60 & 3.67 & 0.55 & - \\
Syncephalastrum sp. & - & 3.97 & 3.35 & - & - \\
\hline
\end{tabular}

- = No fungal growth.

Seventeen fungi were isolated from diseased red Shahi papaya (Table 2). The per cent frequency of C. gloeosporioides was highest (37.49) and A. niger was lowest (5.01) in Segunbagicha bazaar. In Shantinagar bazaar the per cent frequency of $C$. gloeosporioides was highest (24.70) whereas Monilia sp. was lowest (1.05). Colletotrichum gloeosporioides showed highest (27.08) per cent frequency whereas A. alternata showed the lowest (3.46) from Karwan bazaar's samples. Colletotrichum gloeosporioides showed highest (27.88) per cent frequency and Monilia sp. showed lowest (3.62) in the samples collected from Sham bazaar. In the sample collected from Polashi bazaar, the per cent frequency of $C$. gloeosporioides was highest (26.67) and C. lunata was lowest (1.67).

Out of 19 fungal species isolated from papaya fruits three fungi namely, C. gloeosporioides, F. nivale and Fusarium sp. developed characteristic symptoms on the inoculated fruit surface after 7 - 10 days of incubation. They were successfully re-isolated and fulfill Koch's postulate (Fig. 1).

Chowdhury et al. (2014) reported that the frequently occurring diseases of papaya in storage condition were caused by Colletotrichum gloeosporioides, Botryodiploidia theobramae, Fusarium sp. and R. stolonifer in Bangladesh. Rahman et al. (2008) reported a total of seven fungi, namely Botryodiplodia theobromae, Colletotrichum capsici, C. gloeosporioides, Fusarium sp., Phomopsis sp., R. stolonifer and Stemphylium sp. from the surface of fully matured papaya fruits in Malaysia. Among the diseases, the highest incidence ranged from 90 to $98 \%$ and severity of 25 to $38 \%$ was recorded for anthracnose caused by $C$. gloeosporioides followed by stem-end-rot caused by Botryodiplodia theobromae. Lim and Tang (1984) reported that $C$. dematium was the cause for $5 \%$ of anthracnose of papaya in Singapore. Awoite et al. (2013) reported some fungi viz., Aspergillus niger, A. flavus, Rhizopus stolonifer, Penicillum italicum and Neurospora sitophila associated with the spoilage of papaya fruits during their post-harvest period in Nigeria. Akinro et al. (2015) and Baiyewu et al. (2007) reported that Aspergillus sp. and Rhizopus sp. were 
responsible for the soft rots of pawpaw in Nigeria. Gupta and Pathak (1986) reported that Aspergillus niger, A. flavus, Rhizopus nigricans, Curvalaria lanata, Rhizopus oryzae, Fusarium eqiuseti and $F$. moniliforme were responsible for post-harvest losses of pawpaw in south western

Table 2. Per cent frequency of fungi associated with diseased red Shahi papaya collected from different markets of Dhaka city.

\begin{tabular}{lccccc}
\hline $\begin{array}{l}\text { Name of } \\
\text { fungi }\end{array}$ & $\begin{array}{c}\text { Segunbagicha } \\
\text { bazaar }\end{array}$ & $\begin{array}{c}\text { Shantinagar } \\
\text { bazaar }\end{array}$ & $\begin{array}{c}\text { Karwan } \\
\text { bazaar }\end{array}$ & $\begin{array}{c}\text { Sham } \\
\text { bazaar }\end{array}$ & $\begin{array}{c}\text { Polashi } \\
\text { bazaar }\end{array}$ \\
\hline Alternaria alternata & - & 5.00 & 3.46 & - & 2.34 \\
Aspergillus flavus & 9.19 & 5.00 & - & 5.63 & 2.76 \\
A. fumigatus & 7.50 & 4.16 & 7.77 & 6.57 & 5.00 \\
A. niger & 4.07 & 11.42 & 8.61 & 5.00 & 5.00 \\
Colletotrichum gloeosporioides & 37.49 & 24.70 & 27.08 & 27.88 & 26.67 \\
Corynespora citricola & 9.37 & - & 10.45 & - & - \\
Curvularia lunata & 9.60 & 2.49 & 7.21 & & 1.67 \\
Fusarium nivale & - & 16.05 & 12.04 & 19.66 & 12.50 \\
Fusarium sp. & - & 7.88 & 16.52 & 17.33 & 17.45 \\
Lasiodiplodia theobromae & 11.10 & 12.08 & - & - & 18.27 \\
Monilia sp. & - & 1.05 & & 3.62 & - \\
Mucor sp. & 5.01 & 1.52 & - & - & - \\
Penicillium sp. & - & - & 5.89 & 8.45 & - \\
Pestalotiopsis guepinii & 6.67 & - & 7.15 & 5.83 & - \\
Rhizoctonia solani & - & & - & - & 3.34 \\
Rhizopus stolonifer & - & 2.00 & 3.67 & - & 8.05 \\
Syncephalastrum sp. & & 1.57 & 4.09 & - & 1.93 \\
\hline
\end{tabular}

- = No fungal growth.

Nigeria. Oke and Banjoko (1991) have also reported the presence of Penicillium digitatum and Fusarium oxysporium on pawpaw. Ewekeye et al. (2013) reported the occurrence of Rhizopus stolonifer, Aspergillus flavus, A. niger, Mucor sp., Penicillium sp. and Fusarium accuminatum from diseased papaya fruits. Pathak et al. (1976) reported that Fusarium acuminatumn is responsible for the soft rot of papaya in their post-harvest condition. Present results revealed that out of 19 fungal species three were pathogenic to Shahi papaya. From the above discussion it could be said that the association of Curvularia lunata, F. nivale, P. guepinii and Syncephalastrum sp. with post-harvest disease of $C$. papaya is a new record. The fungi Corynespora citricola and Fusarium flocciferum are new record for Bangladesh. Their taxonomic details are given below.

1. Corynespora citricola M.B. Ellis, Z. Pflkrankh. 76:10-13, (1906)

(Fig. 2)

Colonies effuse, grayish, cottony. Mycelium immersed or superficial. Conidiophores brown, straight or flexous, unbranched, conidia mostly solitary, simple, cylindrical, smooth, straw colored, pseudoseptate, $48-350 \times 4.5-8 \mu \mathrm{m}$.

Material studied: Isolated from diseased Carica papaya, Shambazaar, Soarighat, Dhaka, RB Helal 8, 4 July 2016. 

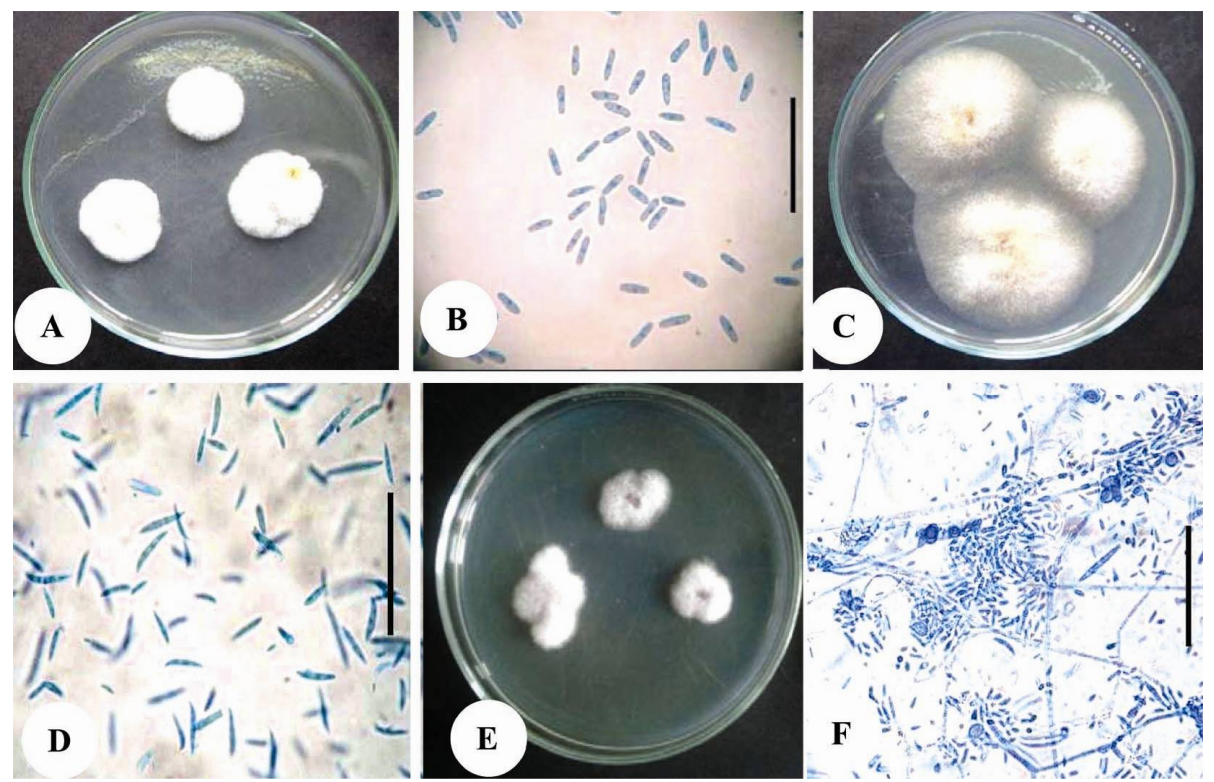

Fig. 1A-D. Colonies and conidia of re-isolated pathogens from Carica papaya. A-B. Colletotrichum gloeosporioides; C-D. Fusarium nivale and E-F. Fusarium sp. Bar $=50 \mu \mathrm{m}$.


Fig. 2A-F. Corynespora citricola: A. Colony on PDA medium, B. Conidiophores with conidia and C. Camera lucida of conidiophores $(\mathrm{Ca})$ and conidia $(\mathrm{Cb})$; Fusarium flocciferum: D. Colony on PDA medium, E. Conidia and F. Camera lucida of conidiophores $(\mathrm{Fa})$ and Conidia $(\mathrm{Fb}) . \mathrm{Bar}=50 \mu \mathrm{m}(\mathrm{B}, \mathrm{E})$ and $11 \mu \mathrm{m}(\mathrm{C}, \mathrm{F})$. 
2. Fusarium flocciferum Corda, sturm's Deutschl. Fl. 2:17, (1828)

(Fig. 2)

Colony light pinkish from both sides. Conidia variable in size, produced from lateral conidiophores in the aerial mycelium. Conidiophores rather loosely branched with 2 - 3 terminal phialides to each branch, $16-22 \times 2-5 \mu \mathrm{m}$. Conidia hyaline straight to curved, indistinctly septate, $22-41 \times 3.5-4.5 \mu \mathrm{m}$.

Material studied: Isolated from diseased Carica papaya, Karwan bazaar, Dhaka, RB Helal 9, 04 July, 2016.

\section{Acknowledgements}

The first author (RBH) expresses her gratitude to the Ministry of Science and Technology, Govt. of the People's Republic of Bangladesh for providing financial assistance to this research work through NST fellowship program.

\section{References}

Ahmed ZU, Hasan MA, Begum ZNT, Khondker M, Kabir SMH, Ahmed M, Ahmed ATA, Rahman AKA and Haque EU (eds.) 2008. Encyclopedia of Flora and Fauna of Bangladesh, Vol. 7. Angiosperms: Dicotyledons (Balsaminaceae- Euphorbiaceae). Asiatic Soc. of Bangladesh, Dhaka. pp. 546.

Akinro EB, Adetuberu IA, Efunwole OO and Olakunle TP 2015. Isolation and identification of fungal species associated with the spoilage of some selected edible fruits in Iree town of Boripe Local Government, Osun State, Nigeria. J. Res. Pharm. Sci. 2(7): 07-10.

Anonymous 2015. Statistical Yearbook of Bangladesh. $27^{\text {th }}$ series, Statistics and Informatics Division, Ministry of Planning, Govt. of the People's Republic of Bangladesh, Dhaka. BBS (Bangladesh Bureau of Statistics). pp.117.

Ara N, Hossain MF and Kaiser MO 2013. Comparative performance of fifteen papaya genotypes. Bull. Inst.Trop. Agr. Kyushu.Univ. 36: 71-78.

Awoite TM, Olorunfemi MF, Ajani AO and Oyelakin MO 2013. Studies on fungi associated with post harvest spoilage of pawpaw Carica papaya fruit. I.O.S.R. J. Pharmacy and Biol. Sciences 4(6): 01- 04.

Baiyewu RA, Amusa NA, Ayoola OA and Babalola OO 2007. Survey of the post-harvest diseases and aflatoxin contamination of marketed pawpaw fruit (Carica papaya) in South Western Nigeria. African J. Agri. Res. 2(4): 178-181.

Bari LP, Hassen N, Absar ME, Haque MIIE, Khuda MM, Pervin S, Khatun and Hossain MI 2006. Nutritional analysis of two varieties of papaya (Carica papaya) at different maturation stages. Pak. J. Biol. Sci. 9: $137-140$.

Barnett HL and Hanter BB 1972. Illustrated Genera of Imperfect Fungi. Burgess Publishing Co, Minneopolis Minnesota. p.15.

Booth C 1971. The Genus Fusarium. Commonwealth Mycological Institute, Kew, Surrey, England. pp. 237.

CAB (Commonwealth Agricultural Bureau) 1968. Plant Pathologist's Pocket Book. $1^{\text {st }}$ edition. The Commonwealth Mycological Institute, England. pp. 267.

Chowdhury SM, Sultana N, Mostofa G, Kundu B and Rashid M 2014. Post harvest diseases of selected fruits in the whole sale market of Dhaka. Bangladesh J. Plant Pathol. 30(1\&2): 13-16.

Ellis MB 1971. Dematiaceous Hyphomycetes. The Commonwealth Mycological Institute, England. pp. 608.

Ewekeye TS, Oke OA, Quadri AI, Isikalu AO, Umenwaniri MO and Durosinmi ML 2013. Studies on post harvest deterioration of some fruits and vegetables in selected markets in Lagos State, Nigeria. American J. Res. Com. 1(10): 209-223.

Gupta AK and Pathak VN 1986. A survey of fruit market for papaya fruit rot by fungal pathogens. Indian J. Mycol. 10: 152-154.

Hamim I, Alam MZ, Ali MA and Ashrafuzzaman M 2014. Incidence post fungal diseases of ripe papaya in Mymensingh. J. Bangladesh Agril. Univ. 12(1): 25-28. 
Lim G and Tang MC 1984. Anthracnose disease of papaya fruit in Singapore. International J. Trop. Plant Dis. 2: 191.

Mendoza EMT 2007. Development of functional foods in the Philippines. Food Sci. Tech. Res. 13: 179-186.

Oke OA and Banjoko KM 1991. The effect of Penicillium digitatum and Fusarium oxysporium rot infections on nutritional content of pawpaw. Mycopathologia. 116: 199-201.

Pathak VN, Goyal JP and Bhatanagar LG 1976. Effect of chemical and hot water treatment on Fusarium and Rhizopus rots of papaya. Indian Phytopath. 29: 210-211.

Rahman MA, Mahmud TMM, Kadir J, Abdul RR and Begum MM 2008. Major postharvest fungal diseases of papaya cv. 'Sekaki' in Selangor, Malaysia. Pertanika J. Trop. Agric. Sci. 31(1): 27 - 34.

Sawant SG and Gawai DU 2011. Effect of fungal infections on nutritional value of papaya fruits. Curr. Bot. 2(1): 43-44.

Sutton BC 1980. The Coelomycetes. Fungi Imperfecti with Pycnidia, Acervuli and Stromata. Commonwealth Mycological Institute, England. pp. 696.

Thom C and Raper KB 1945. A Manual of the Aspergilli. Williams and Wilkins, Baltimore, M.D. USA.

Uddin M. 1995. Market Diseases of Papaya and their Control. MS thesis. Department of Plant Pathology. Bangladesh Agricultural University, Mymensingh.

(Manuscript received on 14 October, 2017; revised on 15 July, 2018) 